International Journal of Informatics, Economics, Management and Science

http://journal.stmikjayakarta.ac.id/index.php/ijiems

E-ISSN: 2809-8471 (online), P-ISSN: 2809-9281 (Print)

DOI: $10.52362 /$ ijiems.v1i1.706

Volume 1 , Issue 1 , January 2022, page 78-101

\title{
Analysis Of the Effect Of E-Accounting And E-Payroll on The Effectiveness
} Of Internal Control

\author{
Herry Wira Wibawa ${ }^{1 *}$ Hendry Muhammad Ali ${ }^{2}$, Dewi Nari Ratih Permada ${ }^{3}$, \\ Verdi Yasin ${ }^{4}$ \\ ${ }^{1}$ Department of Management, Faculty of Economics, University Borobudur, Jakarta, \\ Indonesia \\ ${ }^{2}$ Department of Management, Faculty of Economics, University Borobudur, Jakarta, \\ Indonesia \\ ${ }^{3}$ Department of Accountancy, Faculty of Economics, University Pamulang, Tanggerang, \\ Indonesia \\ ${ }^{4}$ Department of Informatics Engineering, Sekolah Tinggi Manajemen Informatika dan \\ Komputer Jayakarta, Jakarta Indonesia.
}

Authors Scopus ID URL :

Verdi Yasin ${ }^{4,}$ https://www.scopus.com/authid/detail.uri?authorId=57215307401

\section{Email address:}

hwwibawa@gmail.com , hendryali.hayati@gmail.com , dewi.permada@gmail.com , verdiyasin29@gmail.com

*Corresponding author : hwwibawa@gmail.com

Received: December 5, 2021; Accepted: January 7,2022 ; Published: January 8,2022

\begin{abstract}
Purpose of this study is to determine the effect of e-accounting and e-payroll on the effectiveness of internal control partially or simultaneously. The population of this study was 57 employees, and a sample of 57 people was assigned. The sampling technique was carried out by method sampling saturated or census. The data collection technique was carried out using a research instrument in the form of a questionnaire. The collected data was processed with the IBM Statistics SPSS application using the statistical method of multiple regression analysis. The results of this study indicate that partially there is a significant effect between e-accounting on the effectiveness of internal control and e-payroll on the effectiveness of internal control. Simultaneously there is an influence between e-accounting and e-payroll on the effectiveness of internal control. The independent variables, namely eaccounting and e-payroll, affect the dependent variable or the effectiveness of internal control by $92.5 \%$, and $7.5 \%$ is influenced by other variables outside this study..
\end{abstract}

Keywords: e-accounting, e-payroll, effectiveness of internal control

\section{Introduction}

\subsection{Background of the Problem}


International Journal of Informatics, Economics, Management and Science

http://journal.stmikjayakarta.ac.id/index.php/ijiems

E-ISSN: 2809-8471 (online), P-ISSN: 2809-9281 (Print)

DOI: $10.52362 /$ ijiems.v1i1.706

Volume 1 , Issue 1 , January 2022, page 78-101

Salary is one of the expenditure posts that play a role in increasing employee productivity, in its management a systematic plan is needed to coordinate existing facilities to achieve the desired goals so that the company must have a system in the form of appropriate methods and procedures.

E-accounting is important in realizing neat and reliable bookkeeping, according to Romney and Steinbart (2004) is a series consisting of several components, namely people, software data procedures and technological infrastructure that are interconnected and interact to achieve a goal. E-accounting that is well-integrated can support the effectiveness of the company's internal control so that the company can have reliable and relevant financial reports.

In addition to e-accounting in general, $e$-payroll is also the management of human resources owned by the company. Employee salaries should be managed professionally to avoid manipulation by certain parties. Salary management that is not in accordance with procedures can result in employee disappointment so that it can reduce employee productivity. There are several obstacles in realizing an effective e-payroll, including:

1. The existence of a system cut off payroll that is different for each client

2. There is a recording error

3. Late receipt of employee attendance data from clients

Giving salaries and wages to a company to avoid manipulation in payroll the company requires good e-accounting. According to [11] the e-payroll system is designed to handle transactions for calculating employee salaries and wages and their payments.

The most common frauds in payroll include:

1. Fictitious employee, the name of the employee is entered into the payroll file as if working but in fact the name of the employee has never worked for the company.

2. The working hours are not correct; they are made larger than the actual working hours to get more salary.

The e-system is payroll adapted to various government regulations related to taxes and employment practices. According to [11] Internal control system includes organizational structure, methods and measures that are coordinated to maintain organizational wealth, check the accuracy and reliability of accounting data, encourage efficiency, and comply with management policies.

\subsection{Identification of problems}

Identification of problems in this study are as follows:

1. There are still problems withe-accounting payroll

2. E-payroll still has many obstacles and there are frauds

DOI: $10.52362 /$ ijiems.v1i1.706

IJIEMS This work is licensed under a Creative Commons Attribution 4.0 International License. 
International Journal of Informatics, Economics, Management and Science

http://journal.stmikjayakarta.ac.id/index.php/ijiems

E-ISSN: 2809-8471 (online), P-ISSN: 2809-9281 (Print)

DOI: $10.52362 /$ ijiems.v1i1.706

Volume 1 , Issue 1 , January 2022, page 78-101

3. Good e-accounting and e-payroll are needed for the effectiveness of internal control in preventing fraud

4. The problems identified the lack of internal control.

\subsection{Scope of the problem}

Limitations in this study are as follows:

1. Payroll and remuneration control system as the realization of efficient e-payroll

2. Effect of e-accounting and e-payroll on the effectiveness of internal control

\subsection{Problem Formulation}

Based on the background and problem identification above, the problems in this study can be formulated as follows:

1. How much does e-accounting affect the effectiveness of internal control?

2. How much does e-payroll affect the effectiveness of internal control?

3. How much does e-accounting and e-payroll simultaneously affect the effectiveness of internal control?

\subsection{Research Objectives}

Based on the formulation of the problem above, the objectives of this study are as follows:

1. To study and determine the effect of e-accounting on the effectiveness of internal control.

2. To review and determine the effect of e-payroll on the effectiveness of internal control.

3. To study and determine the effect of e-accounting and e-payroll simultaneously on the effectiveness of internal control.

\section{Literature Review}

\subsection{E-accounting Previous}

Researcher [11] defines accounting is the organization of forms, records, and reports that are coordinated in such a way as to provide financial information needed by management to facilitate the management of the company. Based on this definition, the main elements of accounting are forms, records consisting of journals, ledgers and subsidiary ledgers, and reports. According to [5] accounting is a collection of resources, such as people and equipment, which are arranged to convert data into information. This information is communicated to various decision makers. So, e-accounting is a collection of interconnected systems that involve resources such as humans and equipment that work together to manage economic data into the form of financial information that can be used for companies. 
International Journal of Informatics, Economics, Management and Science

http://journal.stmikjayakarta.ac.id/index.php/ijiems

E-ISSN: 2809-8471 (online), P-ISSN: 2809-9281 (Print)

DOI: $10.52362 /$ ijiems.v1i1.706

Volume 1 , Issue 1 , January 2022, page 78-101

Basically, e-accounting is a system that is used to facilitate companies in processing financial data and transactions so that they can produce financial information needed by a company in making decisions.

The e-function accounting can provide or produce quality and useful information for management and other users of information in making decisions. There are three functions of accounting in organizations [16], namely:

1. Collect and store data about the activities carried out by the organization, the resources affected by these activities, and the actors involved in these activities, so that management, employees, and interested outside parties can review (review) things that have happened.

2. Turning data into useful information for management to make decisions in planning, implementation, and monitoring activities.

3. Provide adequate controls to safeguard the organization's assets, including organizational data, to ensure that the data is available when needed, accurate and reliable.

The purpose of e-accounting is to be able to process accounting data from various sources into accounting information needed by various users to reduce risk when making decisions. The main objectives of accounting [12] are as follows:

1. providing information for the management of new business activities in a newly established company requires the development of an accounting system.

2. improve the information generated by the existing system. Often the applicable accounting system cannot meet the needs of management, quality, and information structure contained in the report.

3. improve accounting controls and internal checks. Accounting is the responsibility for the wealth of a company or organization.

4. complement clerical costs in maintaining accounting records. Can be used as economic goods that have many benefits, because to obtain it requires the sacrifice of other economic resources.

The e-accounting element consists of five components [16],

1. The people who operate the system and perform various functions

2. The procedures, both manual and automated, involved in collecting, processing, and storing data about an organization's activities

3. Data about the organization's business processes

4. Software used to process organizational data

5. Information technology infrastructure, including computers, peripheral devices, and equipment for network communications.

DOI: $10.52362 /$ ijiems.v1i1.706

IJIEMS This work is licensed under a Creative Commons Attribution 4.0 International License. 
International Journal of Informatics, Economics, Management and Science

http://journal.stmikjayakarta.ac.id/index.php/ijiems

E-ISSN: 2809-8471 (online), P-ISSN: 2809-9281 (Print)

DOI: $10.52362 /$ ijiems.v1i1.706

Volume 1, Issue 1, January 2022, page 78-101

The e-accounting success measurement model, known as the D\&M Is Success Model (Delone and McLean, 1992) in [10], provides six dimensions of e-accounting success:

\subsubsection{Quality of System}

System Quality means quality of a combination of hardware and software in information systems. The focus is the performance of the system, which shows how well the capabilities of the hardware, software, policies, procedures of the information system can provide the information needs. The measurement indicators of the System Quality from De Lone and Mclean are:

a. Access convenience

The level of success of e-accounting can be seen from the level of user comfort in using the information system. With the high level of comfort of an information system, the user will often use the information system to find the required information

b. System flexibility(flexibility)

Flexibility(flexibility)information systems greatly affect the success rate of the system. Users will prefer a system that is more flexible than a rigid system. With a high level of flexibility, users can more easily.

c. Realization of user expectations

If a system can realize the expectations (expectations) of users in searching for information and system users, the system will be more attractive.

d. The usefulness of specific functions

Each information system can be distinguished from the functions it has, many information systems are more desirable because they have more specific functions than other information systems

\subsubsection{Quality of Information}

Information quality is the output of the user of the information system by the user (user). This variable portray the quality of the information perceived by the user as measured with accuracy accuracy(accuracy), timeliness (timeliness), and presentation of information(format). Indicators of measuring system quality are:

a. Completeness (completeness)

An information generated by the information system can be said to be qualified if the information produced is complete. This complete information is needed by users in making decisions. This complete information includes all the information needed by users in using the information system on a regular basis after being satisfied with the information system.

DOI: $10.52362 /$ ijiems.v1i1.706

IJIEMS This work is licensed under a Creative Commons Attribution 4.0 International License. 
International Journal of Informatics, Economics, Management and Science

http://journal.stmikjayakarta.ac.id/index.php/ijiems

E-ISSN: 2809-8471 (online), P-ISSN: 2809-9281 (Print)

DOI: $10.52362 /$ ijiems.v1i1.706

Volume 1 , Issue 1 , January 2022, page 78-101

b. Relevant(relevance)

The quality of information an information system is said to be good if it is relevant to the needs of the user, or in other words, that information has benefits for users. The relevance of information for each user differs according to needs.

c. Accurate(accurate)

Information generated by the information system must be accurate for very experienced for decision making. Accurate information means free from errors and is not biased or misleading. Accurate also means that information must clearly reflect the intent of the information provided by the information system. Information must be accurate because from the source of information to the recipient of the information, there may be a lot of interference (noise) that can change or damage the information.

d. Timeliness(timeliness)

The information that came at the recipient should not be delayed, outdated information will not have value anymore, because information is a cornerstone in decision making. If the decision is late, it can be fatal for the organization as a user of an information system. Therefore, it can be said that the quality of the information produced by the information system is good if the information produced is timely.

e. The format of

The company's information system that makes it easier for users to understand the information provided by the information system reflects the good quality of information. If the presentation of information is presented in the right form, the information produced is considered quality, making it easier for users to understand the information system produced by an information system. Information format refers to how information is presented to users. The two components of an information format are the basic form and context of its interpretation which is sometimes seen as a frame. The basic form of the format is a form of presenting the website as a form of information system, while the context of the interpretation of the information system affects the views of users and this often causes misunderstandings.

f. Service Quality (Quality of Service)

Information system service quality is a service that users get from information system developers, services can be in the form of updating information systems and responses from developers if information has problems

\subsubsection{Usage}

Use refers to how often users use the information system. In this regard, it is important to distinguish whether use is mandatory or voluntary. This variable is measured by the 
International Journal of Informatics, Economics, Management and Science

http://journal.stmikjayakarta.ac.id/index.php/ijiems

E-ISSN: 2809-8471 (online), P-ISSN: 2809-9281 (Print)

DOI: $10.52362 /$ ijiems.v1i1.706

Volume 1, Issue 1, January 2022, page 78-101

indicators used which consist of one item, namely how often users (users) use the information system (frequency of use)

\subsubsection{User satisfaction}

Satisfaction is the response and feedback that the user raises after using the information system. The user's attitude towards the information system is a subjective criterion of how much the user likes the system used. This variable is supported by indicators consisting of efficiency, effectiveness, and satisfaction.

a. Efficiency

User satisfaction can be achieved if the information system requires users efficiently. This efficiency can be seen from the information system that can provide solutions to user work related to data reporting activities efficiently. An information system can be said to be efficient if a user's goals can be achieved by doing the right things.

b. Effectiveness the

Effectiveness of information systems in meeting user needs can result in user satisfaction with the information system. The effectiveness of this information system can be seen from the needs or goals of the user can be achieved in accordance with the front or the desired target.

c. Satisfaction

User satisfaction can be measured through the satisfaction felt by users in using library information systems. User satisfaction can be generated from the features provided by the system. Library information and the quality of system information generated by the library information system. The satisfaction felt by the user indicates that the information system has succeeded in meeting the aspirations or needs of the user.

\subsubsection{Company profit}

Company profit are the impact (impact) the existence and use of information systems on the quality of work individually and in organizations including productivity, increasing knowledge and reducing the length of time searching for information.

\subsection{E-payroll}

According to [11], e-payroll and wages are a system designed to handle transactions for calculating employee salaries and wages and their payments. This system consists of the following network of procedures: attendance and work time recording procedures, payroll and wage register procedures, salary and wage payment procedures, and salary and wage cost

DOI: $10.52362 /$ ijiems.v1i1.706

IJIEMS This work is licensed under a Creative Commons Attribution 4.0 International License. 
International Journal of Informatics, Economics, Management and Science

http://journal.stmikjayakarta.ac.id/index.php/ijiems

E-ISSN: 2809-8471 (online), P-ISSN: 2809-9281 (Print)

DOI: $10.52362 /$ ijiems.v1i1.706

Volume 1, Issue 1, January 2022, page 78-101

distribution procedures. According to Romney (2005), e-payroll is a series of recurring business activities and related data processing operations related to effective ways of managing employees. According to [3], the definition of e-payroll is a framework of interconnected procedures according to a comprehensive scheme to carry out the company's main activities and functions.

Based on the opinion above, it can be concluded that e-payroll is a series of procedures related to calculating employee salaries and wages to payment. There are several indicators of epayroll [22], namely:

1. Job Analysis

In job analysis the company determines the specifications in advance, for example the requirements for occupying a position, education level, experience, etc.

2. Cooperation Bonds Cooperation

Between companies and employees, namely determining the salary received after doing a job with the required requirements.

3. Salary Survey

Conducted to ensure fairness in giving salaries to employees.

4. Determining the Price and Each Job

Related to comparing the price for each job according to the level of difficulty.

\subsection{Effectiveness of internal control}

According to [11], the internal control system includes the organizational structure, methods and measures that are coordinated to maintain organizational wealth, check the accuracy and reliability of accounting data, encourage efficiency, and encourage compliance with management policies. Romney (2006) states that internal control is an organizational plan and business method used to safeguard assets, provide accurate and reliable information, encourage and improve the efficiency of the organization's operations and encourage conformity with established policies.

According to [8] in a narrow sense the internal control system is a mechanical procedure to check the accuracy of administrative data, such as matching a horizontal sum (horizontal) with a straight (vertical) summation. In a broad sense, the internal control system can be seen as a social system that has special insight or meaning within the company's organization. Furthermore, the AICPA (American Institute of Certified Public Accountants) in [8] defines the internal control system as covering the organizational structure, all methods and coordinated provisions adopted in the company to protect assets, check accuracy, and how far the data reliable accounting, improve business efficiency and encourage compliance with established company policies.

DOI: $10.52362 /$ ijiems.v1i1.706

IJIEMS This work is licensed under a Creative Commons Attribution 4.0 International License. 
International Journal of Informatics, Economics, Management and Science

http://journal.stmikjayakarta.ac.id/index.php/ijiems

E-ISSN: 2809-8471 (online), P-ISSN: 2809-9281 (Print)

DOI: $10.52362 /$ ijiems.v1i1.706

Volume 1, Issue 1, January 2022, page 78-101

Based on some of the definitions above, internal control is internal control is a set of policies and procedures that are influenced by the board of directors, management and employees that are designed to provide assurance on the effectiveness and efficiency of operations, reliability of financial reporting and compliance with applicable laws and regulations.

According to COSO in [17] internal control components:

\subsubsection{Control Environment}

At the heart of any business are its people (individual traits, including integrity, ethical values, and competence) and the environment in which it operates. They are the engine that drives the organization and the foundation on which everything rests.

\subsubsection{Control Activities Control}

Policies and procedures must be established and implemented to help ensure that Actions identified by management to address risks to the achievement of organizational objectives are effectively implemented.

\subsubsection{Risk Assessment The}

Organization must be patient with and deal with the risks it faces. The organization must set goals, which are integrated with sales, production, marketing, finance and other activities for the organization to operate in harmony. The organization should also establish mechanisms to identify, analyze and manage the associated risks.

\subsubsection{Information and Communication}

Around the control activities are information and communication systems. They enable people in an organization to obtain and exchange the information needed to carry out, manage and control its operations.

\subsubsection{Supervision The}

Entire process should be monitored, and changes made as needed. In this way, the system can act dynamically, changing according to the demands of the situation.

Internal control is a series of processes both in the form of procedures and policies consisting of supporting components to provide adequate assurance to management that the organization will be able to achieve its goals and minimize the occurrence of fraud. Based on the theory above, in this study the researcher uses the dimensions of internal control consisting of the control environment, risk assessment, control activities, information and communication and supervisory activities.

DOI: $10.52362 /$ ijiems.v1i1.706

IJIEMS This work is licensed under a Creative Commons Attribution 4.0 International License. 
International Journal of Informatics, Economics, Management and Science

http://journal.stmikjayakarta.ac.id/index.php/ijiems

E-ISSN: 2809-8471 (online), P-ISSN: 2809-9281 (Print)

DOI: $10.52362 /$ ijiems.v1i1.706

Volume 1 , Issue 1 , January 2022, page 78-101

\subsubsection{Previous Research}

Table.1. Previous Research

\begin{tabular}{|c|c|c|c|c|}
\hline $\mathbf{N}$ & Researcher & $\begin{array}{c}\text { The Title of Object } \\
\text { Research }\end{array}$ & Analysis Method & Results \\
\hline 1 & $\begin{array}{l}\text { Rofily } \\
\text { Putriyandari } \\
(2014)\end{array}$ & $\begin{array}{l}\text { "The Effect of Payroll e- } \\
\text { accounting on the } \\
\text { Effectiveness of Internal } \\
\text { Control Structures at the } \\
\text { Plantation Service of } \\
\text { West Java Province" }\end{array}$ & $\begin{array}{l}\text { Descriptive } \\
\text { quantitative } \\
\text { method. The } \\
\text { research variables } \\
\text { are E-accounting, } \\
\text { Payroll, and } \\
\text { Internal Control. }\end{array}$ & $\begin{array}{l}\text { The extent to which } \\
\text { payroll e-accounting } \\
\text { on internal control. }\end{array}$ \\
\hline 2 & $\begin{array}{l}\text { Rio } \\
\text { Kencono } \\
(2016)\end{array}$ & $\begin{array}{l}\text { "The Influence of E- } \\
\text { payroll on the } \\
\text { Effectiveness of Internal } \\
\text { Salary Control (Case } \\
\text { Study on SPPBE PT } \\
\text { Puspita Cipta in } \\
\text { Kuningan)". }\end{array}$ & $\begin{array}{l}\text { Analytical } \\
\text { descriptive } \\
\text { method }\end{array}$ & $\begin{array}{l}\text { E-accounting } \\
\text { adequate salary plays } \\
\text { a role in supporting } \\
\text { the effectiveness of } \\
\text { salary internal } \\
\text { control. }\end{array}$ \\
\hline 3 & $\begin{array}{l}\text { Mohammad } \\
\text { Taufiq } \\
\text { Hidayat, Sri } \\
\text { Mangesti } \\
\text { Rahayu, } \\
\text { Achmad } \\
\text { Husaini } \\
\text { (2013) }\end{array}$ & $\begin{array}{l}\text { "Analysis of the } \\
\text { Application of E-payroll } \\
\text { and Wages in Supporting } \\
\text { Internal Control (Case } \\
\text { Study at PT. Cahaya } \\
\text { Marta Perkasa, } \\
\text { Pamekasan)" }\end{array}$ & $\begin{array}{l}\text { Analytical } \\
\text { descriptive } \\
\text { method }\end{array}$ & $\begin{array}{l}\text { There are differences } \\
\text { in the process of } \\
\text { providing employee } \\
\text { salaries where } \\
\text { employees Fixed and } \\
\text { piece rate salaries are } \\
\text { given monthly, while } \\
\text { daily employees are } \\
\text { paid weekly. }\end{array}$ \\
\hline 4 & $\begin{array}{l}\text { Sri Lestari } \\
\text { Pebrianti, et } \\
\text { al (2020) }\end{array}$ & $\begin{array}{l}\text { "The Effect of E- } \\
\text { accounting on the } \\
\text { Effectiveness of Internal } \\
\text { Control at PT Bosowa }\end{array}$ & $\begin{array}{l}\text { Simple Linear } \\
\text { Regression } \\
\text { Analysis Method. } \\
\text { The variable is }\end{array}$ & $\begin{array}{l}\text { knowing the effect of } \\
\text { E-accounting on the } \\
\text { Effectiveness of } \\
\text { Internal Control at }\end{array}$ \\
\hline
\end{tabular}


International Journal of Informatics, Economics, Management and Science

http://journal.stmikjayakarta.ac.id/index.php/ijiems

E-ISSN: 2809-8471 (online), P-ISSN: 2809-9281 (Print)

DOI: $10.52362 /$ ijiems.v1i1.706

Volume 1 , Issue 1 , January 2022, page 78-101

\begin{tabular}{|l|l|l|}
$\mid$ Berlian Motor Makassar" & $\begin{array}{l}\text { PT Bosowa Berlian } \\
\text { Motor Makassar }\end{array}$ \\
\hline
\end{tabular}

\subsubsection{Framework of Thought}

In a framework of thinking definitively the concept of influence is defined as a relationship of the independent variable to the dependent variable. The variables used are

1. The independent variables are e-accounting and e-payroll.

2. The dependent variable is the effectiveness of internal control.

To clarify the framework of thought above, the three variables can be described in a simple paradigm with two independent variables and one dependent variable, as follows

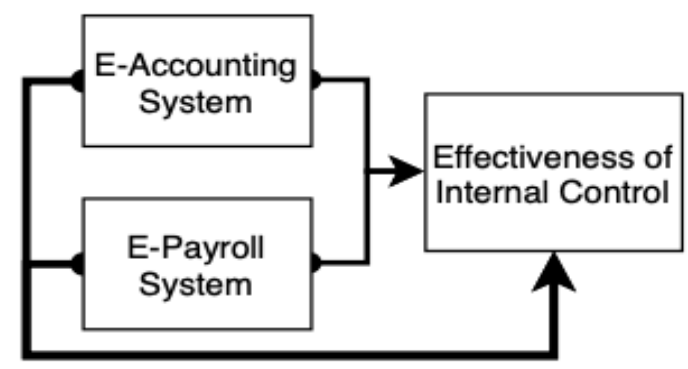

Figure.1. Thinking Framework

\subsubsection{Hypothesis Development}

hypotheses in this study are:

$H_{1}=$ E-accounting has a significant positive effect on the effectiveness of internal control

$\mathrm{H}_{2}=\mathrm{E}-$ payroll has a significant positive effect on the effectiveness of internal control

$H_{3}=$ E-accounting and e-payroll simultaneously have a significant positive effect on the effectiveness of internal control

\section{Research Methodology}

\subsection{Data Sources}

In collecting data sources, researchers collect primary data sources. The researcher distributed several questions in the form of a questionnaire or a google form using ascale Likert 4-pointregarding e-accounting and e-payroll on the effectiveness of internal control. The operational definition of this research variable can be seen in the following table:

Table.2. Operational Variables

\begin{tabular}{|c|l|l|c|}
\hline Variables & \multicolumn{1}{|c|}{ Definition of } & \multicolumn{1}{c|}{ Indicators } & Scale of \\
\hline $\begin{array}{c}\text { e-accounting } \\
\left(\mathrm{X}_{1}\right)\end{array}$ & $\begin{array}{l}\text { e-accounting is a collection of } \\
\text { resources such as people and }\end{array}$ & $\begin{array}{l}\text { 1. Quality of system } \\
\text { 2. Quality of Information }\end{array}$ & Likert \\
\hline
\end{tabular}


International Journal of Informatics, Economics, Management and Science

http://journal.stmikjayakarta.ac.id/index.php/ijiems

E-ISSN: 2809-8471 (online), P-ISSN: 2809-9281 (Print)

DOI: $10.52362 /$ ijiems.v1i1.706

Volume 1, Issue 1, January 2022, page 78-101

\begin{tabular}{|c|c|c|c|}
\hline & $\begin{array}{l}\text { equipment, which are } \\
\text { arranged to convert data into } \\
\text { information. } \\
\text { Bodnar and Hopwood (2000) }\end{array}$ & $\begin{array}{l}\text { 3. Service Quality } \\
\text { 4. Usage } \\
\text { 5. User satisfaction } \\
\text { 6. Company Profit } \\
\text { Resource by Jogiyanto } \\
(2007)\end{array}$ & \\
\hline e-payroll $\left(\mathrm{X}_{2}\right)$ & $\begin{array}{l}\text { e-payroll is a system designed } \\
\text { to handle transactions for } \\
\text { calculating employee salaries } \\
\text { and wages and their payments. } \\
\text { Mulyadi (2001) }\end{array}$ & $\begin{array}{l}\text { 1. Job analysis } \\
\text { 2. Cooperation bond } \\
\text { 3. Salary survey } \\
\text { 4. Determining the price and } \\
\text { each job } \\
\text { Resource by William B. } \\
\text { Wether and Keith Davis } \\
(1993)\end{array}$ & Likert \\
\hline $\begin{array}{l}\text { internal } \\
\text { control } \\
\text { effectiveness } \\
(\mathrm{Y})\end{array}$ & $\begin{array}{l}\text { Internal control system } \\
\text { includes } \\
\text { structure, } \\
\text { organizational } \\
\text { coordinated } \\
\text { maintain measures to } \\
\text { wealth, check accuracy and } \\
\text { reliability of accounting data, } \\
\text { promote efficiency and } \\
\text { encourage compliance with } \\
\text { management policies. } \\
\text { Mulyadi (2001) }\end{array}$ & $\begin{array}{l}\text { 1. Control environment } \\
\text { 2. Control activities } \\
\text { 3. Risk assessment } \\
\text { 4. Information and } \\
\text { communication } \\
\text { 5. Oversight } \\
\text { COSO in Romney (2006) }\end{array}$ & Likert \\
\hline
\end{tabular}

\subsection{Sampling Techniques}

According to [19] population is an area consisting of objects/subjects that have certain qualities and characteristics determined by researchers to be studied and then drawn conclusions. The population in this study were 57 employees.

According to [19] the sample is part of the number and characteristics possessed by the population. The sample is considered as representative of the population whose results represent the overall observed symptoms. The data analyzed in a study is the measurement data from the sample.

DOI: $10.52362 /$ ijiems.v1i1.706

IJIEMS This work is licensed under a Creative Commons Attribution 4.0 International License. 
International Journal of Informatics, Economics, Management and Science

http://journal.stmikjayakarta.ac.id/index.php/ijiems

E-ISSN: 2809-8471 (online), P-ISSN: 2809-9281 (Print)

DOI: $10.52362 /$ ijiems.v1i1.706

Volume 1 , Issue 1 , January 2022, page 78-101

According to [2] if the population is less than 100 people, then the total sample is taken, but if the population is greater than 100 people, then $10-15 \%$ or $20-25 \%$ of the total population can be taken.

Based on this study, because the population is not greater than 100 respondents, the authors take $100 \%$ of the existing population of 57 respondents. Thus, the use of the entire population without having to draw a research sample as a unit of observation is referred to as a census technique. According to [19], sampling saturated is a technique when all members of the population are used as samples. Another term for saturated sample is census.

\section{Results And Discussion}

\subsection{Description of Respondents}

Researchers used primary data with a questionnaire as a data collection tool. The number of questionnaires distributed and returned to the researchers were 57 copies with 10 question items for each variable. The following are the results of the questionnaire answers from respondents who were collected:

Table.3. Respondents Variable e-accounting $\left(X_{1}\right)$

\begin{tabular}{|c|c|c|c|c|c|c|c|}
\hline \multirow{2}{*}{ Indicator } & \multirow{2}{*}{ Code } & \multicolumn{4}{|c|}{ Score } & \multirow{2}{*}{ Amount } & \multirow{2}{*}{ Average } \\
\hline & & 1 & 2 & 4 & 4 & & \\
\hline \multirow{4}{*}{ System Quality } & \multirow{2}{*}{$\mathrm{X}_{1.1}$} & 0 & 7 & 14 & 36 & 57 & \multirow{2}{*}{3,51} \\
\hline & & 0 & 14 & 42 & 144 & 200 & \\
\hline & \multirow{2}{*}{$\mathrm{X}_{1.2}$} & 0 & 8 & 18 & 31 & 57 & \multirow{2}{*}{3,40} \\
\hline & & 0 & 16 & 54 & 124 & 194 & \\
\hline \multirow{6}{*}{$\begin{array}{c}\text { Information } \\
\text { Quality }\end{array}$} & \multirow{2}{*}{$\mathrm{X}_{1.3}$} & 0 & 11 & 17 & 29 & 57 & \multirow{2}{*}{3,32} \\
\hline & & 0 & 22 & 51 & 116 & 189 & \\
\hline & \multirow[b]{2}{*}{$\mathrm{X}_{1.4}$} & 0 & 14 & 22 & 21 & 57 & \multirow{2}{*}{3,12} \\
\hline & & 0 & 28 & 66 & 84 & 178 & \\
\hline & \multirow{2}{*}{$\mathrm{X}_{1.5}$} & 0 & 9 & 22 & 26 & 57 & \multirow{2}{*}{3,30} \\
\hline & & 0 & 18 & 66 & 104 & 188 & \\
\hline \multirow{4}{*}{ Service Quality } & \multirow{2}{*}{$\mathrm{X}_{1.6}$} & 0 & 11 & 21 & 25 & 57 & \multirow{2}{*}{3,25} \\
\hline & & 0 & 22 & 63 & 100 & 185 & \\
\hline & \multirow{2}{*}{$\mathrm{X}_{1.7}$} & 0 & 16 & 20 & 21 & 57 & \multirow{2}{*}{3,09} \\
\hline & & 0 & 32 & 60 & 84 & 176 & \\
\hline \multirow{2}{*}{ Use } & \multirow{2}{*}{$\mathrm{X}_{1.8}$} & 0 & 13 & 11 & 33 & 57 & \multirow{2}{*}{3,35} \\
\hline & & 0 & 26 & 33 & 132 & 191 & \\
\hline \multirow{2}{*}{ User Satisfaction } & \multirow{2}{*}{$\mathrm{X}_{1.9}$} & 0 & 13 & 19 & 25 & 57 & \multirow{2}{*}{3,21} \\
\hline & & 0 & 26 & 57 & 100 & 183 & \\
\hline
\end{tabular}


International Journal of Informatics, Economics, Management and Science

http://journal.stmikjayakarta.ac.id/index.php/ijiems

E-ISSN: 2809-8471 (online), P-ISSN: 2809-9281 (Print)

DOI: $10.52362 /$ ijiems.v1i1.706

Volume 1, Issue 1, January 2022, page 78-101

\begin{tabular}{|c|c|c|c|c|c|c|c|}
\hline \multirow{2}{*}{ Net Benefit } & & 0 & 7 & 21 & 29 & 57 & \multirow{2}{*}{3,39} \\
\hline & $\mathrm{X}_{1.10}$ & 0 & 14 & 63 & 116 & 193 & \\
\hline \multicolumn{6}{|c|}{ Variabe mean of e-accounting } & 1877 & 3,29 \\
\hline
\end{tabular}

Source: Processed data, 2020

Based on the respondent's answer, the statement X1.7 of the product quality variable is the answer with the lowest value "E-accounting can be operated during working hours comfortably without any problems.". While the value of X1.1 which reads "E-accounting in the company has the convenience to be accessed whenever needed "is the highest score.

Table 4 Respondents Variable e-payroll $\left(\mathrm{X}_{2}\right)$

\begin{tabular}{|c|c|c|c|c|c|c|c|}
\hline \multirow{2}{*}{ Indicator } & \multirow{2}{*}{ Code } & \multicolumn{4}{|c|}{ Score } & \multirow{2}{*}{$\begin{array}{c}\text { Amoun } \\
\mathbf{t}\end{array}$} & \multirow{2}{*}{$\begin{array}{c}\text { Averag } \\
\text { e }\end{array}$} \\
\hline & & 1 & 2 & 3 & 4 & & \\
\hline \multirow{8}{*}{ Job Analysis } & \multirow{2}{*}{$\mathrm{X}_{2.1}$} & 0 & 9 & 17 & 31 & 57 & \multirow{2}{*}{3,39} \\
\hline & & 0 & 18 & 51 & 124 & 193 & \\
\hline & \multirow{2}{*}{$\mathrm{X}_{2.2}$} & 0 & 9 & 19 & 29 & 57 & \multirow{2}{*}{3,35} \\
\hline & & 0 & 18 & 57 & 116 & 191 & \\
\hline & \multirow{2}{*}{$\mathrm{X}_{2.3}$} & 0 & 10 & 22 & 25 & 57 & \multirow{2}{*}{3,26} \\
\hline & & 0 & 20 & 66 & 100 & 186 & \\
\hline & \multirow{2}{*}{$\mathrm{X}_{2.4}$} & 0 & 13 & 17 & 27 & 57 & \multirow{2}{*}{3,24} \\
\hline & & 0 & 26 & 51 & 108 & 185 & \\
\hline \multirow{4}{*}{ Cooperation Bond } & \multirow{2}{*}{$\mathrm{X}_{2.5}$} & 0 & 10 & 23 & 24 & 57 & \multirow{2}{*}{3,24} \\
\hline & & 0 & 20 & 69 & 96 & 185 & \\
\hline & \multirow{2}{*}{$\mathrm{X}_{2.6}$} & 0 & 14 & 21 & 22 & 57 & \multirow{2}{*}{3,14} \\
\hline & & 0 & 28 & 63 & 88 & 179 & \\
\hline \multirow{4}{*}{ Salary Survey } & \multirow{2}{*}{$\mathrm{X}_{2.7}$} & 0 & 8 & 18 & 31 & 57 & \multirow{2}{*}{3,40} \\
\hline & & 0 & 16 & 54 & 124 & 194 & \\
\hline & \multirow{2}{*}{$\mathrm{X}_{2.8}$} & 0 & 7 & 20 & 30 & 57 & \multirow{2}{*}{3,40} \\
\hline & & 0 & 14 & 60 & 120 & 194 & \\
\hline \multirow{4}{*}{$\begin{array}{c}\text { Determine the price } \\
\text { and each job }\end{array}$} & \multirow{2}{*}{$\mathrm{X}_{2.9}$} & 0 & 13 & 14 & 30 & 57 & \multirow{2}{*}{3,30} \\
\hline & & 0 & 26 & 42 & 120 & 188 & \\
\hline & \multirow{2}{*}{$\mathrm{X}_{2.10}$} & 0 & 10 & 18 & 29 & 57 & \multirow{2}{*}{3,33} \\
\hline & & 0 & 20 & 54 & 116 & 190 & \\
\hline \multicolumn{6}{|c|}{ Variable mean of e-payroll } & 1885 & 3,31 \\
\hline
\end{tabular}

Source: Processed data, 2020

Based on respondents' answers, the statement X2.6 variable product quality is the answer with the lowest value "The list of salaries and wages is made individually with various kinds of 
International Journal of Informatics, Economics, Management and Science

http://journal.stmikjayakarta.ac.id/index.php/ijiems

E-ISSN: 2809-8471 (online), P-ISSN: 2809-9281 (Print)

DOI: $10.52362 /$ ijiems.v1i1.706

Volume 1 , Issue 1 , January 2022, page 78-101

information that forms it and shows the amount gross salary and wages.". While the values of X2.7 and X2.8 which read "The attendance card functions to calculate wages that will be received by employees according to the number of days of attendance, except for permanent employees." and "Checking salary and wage accounts are carried out by the company regularly" are the highest values.

Table 4.3 Respondents Internal control effectiveness variable (Y)

\begin{tabular}{|c|c|c|c|c|c|c|c|}
\hline \multirow[b]{2}{*}{ Indicator } & \multirow[b]{2}{*}{ Code } & \multicolumn{4}{|c|}{ Score } & \multirow[b]{2}{*}{ Amoun } & \multirow[b]{2}{*}{ Average } \\
\hline & & 1 & 2 & 3 & 4 & & \\
\hline \multirow{6}{*}{$\begin{array}{c}\text { Control } \\
\text { Environment }\end{array}$} & \multirow[b]{2}{*}{ Y1 } & 0 & 9 & 13 & 35 & 57 & \multirow[b]{2}{*}{3,46} \\
\hline & & 0 & 18 & 39 & 140 & 197 & \\
\hline & \multirow[b]{2}{*}{$\mathrm{Y} 2$} & 0 & 7 & 7 & 43 & 57 & \multirow[b]{2}{*}{3,63} \\
\hline & & 0 & 14 & 21 & 172 & 207 & \\
\hline & \multirow[b]{2}{*}{ Y3 } & 0 & 18 & 19 & 20 & 57 & \multirow[b]{2}{*}{3,04} \\
\hline & & 0 & 36 & 57 & 80 & 173 & \\
\hline \multirow{6}{*}{ Control Activities } & \multirow[b]{2}{*}{ Y4 } & 0 & 11 & 20 & 26 & 57 & \multirow[b]{2}{*}{3,26} \\
\hline & & 0 & 22 & 60 & 104 & 186 & \\
\hline & \multirow[b]{2}{*}{ Y5 } & 0 & 16 & 22 & 19 & 57 & \multirow[b]{2}{*}{3,05} \\
\hline & & 0 & 32 & 66 & 76 & 174 & \\
\hline & \multirow[b]{2}{*}{ Y6 } & 0 & 12 & 12 & 33 & 57 & \multirow[b]{2}{*}{3,37} \\
\hline & & 0 & 24 & 36 & 132 & 192 & \\
\hline \multirow[b]{2}{*}{ Risk Assessment } & \multirow[b]{2}{*}{ Y7 } & 0 & 12 & 21 & 24 & 57 & \multirow[b]{2}{*}{3,21} \\
\hline & & 0 & 24 & 63 & 96 & 183 & \\
\hline \multirow{6}{*}{$\begin{array}{l}\text { Information and } \\
\text { Communication }\end{array}$} & \multirow[b]{2}{*}{ Y8 } & 0 & 8 & 18 & 31 & 57 & \multirow[b]{2}{*}{3,40} \\
\hline & & 0 & 16 & 54 & 124 & 194 & \\
\hline & \multirow[b]{2}{*}{ Y9 } & 0 & 11 & 17 & \begin{tabular}{|l|}
29 \\
\end{tabular} & 57 & \multirow[b]{2}{*}{3,16} \\
\hline & & 0 & 22 & 51 & 116 & 189 & \\
\hline & \multirow[b]{2}{*}{ Y10 } & 0 & 12 & 18 & \begin{tabular}{|l|}
27 \\
\end{tabular} & 57 & \multirow[b]{2}{*}{3,26} \\
\hline & & 0 & 24 & 54 & 108 & 186 & \\
\hline \multicolumn{6}{|c|}{$\begin{array}{c}\text { Mean Variable of internal control } \\
\text { effectiveness }\end{array}$} & 1881 & 3,30 \\
\hline
\end{tabular}

Source: Processed data, 2020 
International Journal of Informatics, Economics, Management and Science

http://journal.stmikjayakarta.ac.id/index.php/ijiems

E-ISSN: 2809-8471 (online), P-ISSN: 2809-9281 (Print)

DOI: $10.52362 /$ ijiems.v1i1.706

Volume 1, Issue 1, January 2022, page 78-101

Based on the respondents' answers, the statement $\mathrm{Y} 3$ of the product quality variable is the answer with the lowest value "There is an organizational structure and a clear job description". While the value of Y2 which reads "Employees are placed according to their knowledge and skills" is the highest value.

\subsection{Data Quality Test}

1. Validity

Test The significance test was carried out by comparing the calculated $\mathrm{r}$ value with the $\mathrm{r}$ table for degree of freedom ( $\mathrm{df})=\mathrm{n}-2$, in this case $\mathrm{n}$ is the number of samples. So the $\mathrm{df}$ used is 57$2=55$ with an alpha of $5 \%$, resulting in a value of $r$ table (two-sided test) of 0.2609 . A statement item can be said to be valid if the corrected item-total correlation $>\mathrm{r}$ table, with a significance level of $5 \%$.

The results of validity testing for the variables used in this study can be seen below:

Table 4.4 E-accounting Validity Test Results $\left(X_{1}\right)$

\begin{tabular}{|c|c|c|c|}
\hline $\begin{array}{c}\text { Statement } \\
\text { Number }\end{array}$ & r coun & $\mathbf{r}$ table & Remarks \\
\hline 1 & 0,752 & 0.2609 & Valid \\
\hline 2 & 0,753 & 0.2609 & Valid \\
\hline 3 & 0,749 & 0.2609 & Valid \\
\hline 4 & 0,661 & 0.2609 & Valid \\
\hline 5 & 0,740 & 0.2609 & Valid \\
\hline 6 & 0,755 & 0.2609 & Valid \\
\hline 7 & 0,639 & 0.2609 & Valid \\
\hline 8 & 0,795 & 0.2609 & Valid \\
\hline 9 & 0,715 & 0.2609 & Valid \\
\hline 10 & 0,760 & 0.2609 & Valid \\
\hline
\end{tabular}

Source: Processed primary data, 2020

The e-accounting variable $\left(\boldsymbol{X}_{\mathbf{1}}\right)$ has a calculated $\mathrm{r}$ value greater than $\mathrm{r}$ table 0.2609 which means that all question items for the e-accounting variable $\left(\boldsymbol{X}_{\mathbf{1}}\right)$ are declared valid.

Table 4.5 E-payroll Validity Test Results $\left(X_{2}\right)$

\begin{tabular}{|c|c|c|c|}
\hline Statement Number & r count & $\mathbf{r}$ table & Remarks \\
\hline 11 & 0,680 & 0.2609 & Valid \\
\hline 12 & 0,814 & 0.2609 & Valid \\
\hline 13 & 0,622 & 0.2609 & Valid \\
\hline 14 & 0,718 & 0.2609 & Valid \\
\hline 15 & 0,649 & 0.2609 & Valid \\
\hline 16 & 0,700 & 0.2609 & Valid \\
\hline 17 & 0,807 & 0.2609 & Valid \\
\hline 18 & 0,776 & 0.2609 & Valid \\
\hline 19 & 0,708 & 0.2609 & Valid \\
\hline
\end{tabular}


International Journal of Informatics, Economics, Management and Science

http://journal.stmikjayakarta.ac.id/index.php/ijiems

E-ISSN: 2809-8471 (online), P-ISSN: 2809-9281 (Print)

DOI: $10.52362 /$ ijiems.v1i1.706

Volume 1, Issue 1, January 2022, page 78-101

Source: Processed primary data, 2020

The e-payroll variable $\left(\mathrm{X}_{2}\right)$ has a calculated $\mathrm{r}$ value greater than $\mathrm{r}$ table 0.2609 which means that all question items for the e-payroll variable $\left(\mathrm{X}_{2}\right)$ are declared valid.

Table 4.6 Internal Control Validity Test Results (Y)

\begin{tabular}{|c|c|c|c|}
\hline $\begin{array}{c}\text { Statement } \\
\text { Number }\end{array}$ & $\begin{array}{c}\mathbf{r} \\
\text { count }\end{array}$ & $\mathbf{r}$ table & Remark \\
$\mathbf{s}$
\end{tabular}

Source: Processed primary data, 2020

Internal control effectiveness variable (Y) has an $r$ value greater than $r$ table 0.2609 which means that all question items are for the Effectiveness variable of internal control effectiveness (Y) declared valid.

2. Reliability Test

Table 4.7 Reliability Test Results

\begin{tabular}{|c|c|c|c|}
\hline Variabel & $\begin{array}{c}\text { Cronbach's } \\
\text { Alpha }\end{array}$ & $\begin{array}{c}\text { Provisio } \\
\mathbf{n}\end{array}$ & $\begin{array}{c}\text { Remark } \\
\text { S }\end{array}$ \\
\hline e-accounting $\left(\mathrm{X}_{1}\right)$ & 0,903 & 0,60 & Reliabel \\
\hline e-payroll $\left(\mathrm{X}_{2}\right)$ & 0,897 & 0,60 & Reliabel \\
\hline $\begin{array}{c}\text { Internal control } \\
\text { effectiveness (Y) }\end{array}$ & 0,896 & 0,60 & Reliabel \\
\hline
\end{tabular}

Source: Processed Data, 2020

The results of testing the reliability of the questionnaire resulted in Cronbach's Alpha of 0.903 for the e-accounting variable, 0.897 for the e-payroll variable, 0.896 for the internal control effectiveness variable. Based on these results, the value of Cronbach's alpha of all variables shows a number greater than 0.60 , it can be concluded that all statements of all variables in this study were tested for reliability.

\subsection{Classical Assumption Test}

\subsubsection{Normality Test}

a. Graphic Analysis

DOI: $10.52362 /$ ijiems.v1i1.706

IJIEMS This work is licensed under a Creative Commons Attribution 4.0 International License. 
International Journal of Informatics, Economics, Management and Science

http://journal.stmikjayakarta.ac.id/index.php/ijiems

E-ISSN: 2809-8471 (online), P-ISSN: 2809-9281 (Print)

DOI: $10.52362 /$ ijiems.v1i1.706

Volume 1, Issue 1, January 2022, page 78-101

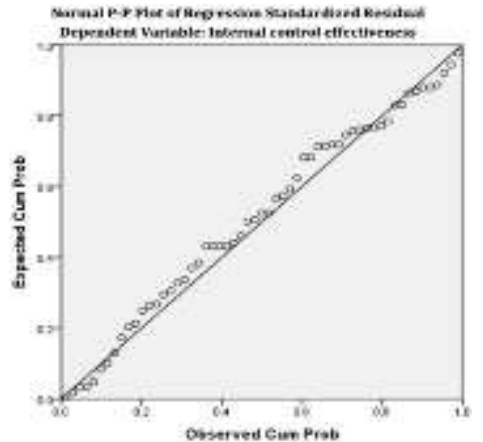

Source: Processed data, 2020

Figure 4.1 P-Plot Graph Grafik

From the P-Plot graph above, it can be concluded that the points spread around the diagonal line, and the spread follows and approaches the diagonal line. This shows that the regression model is feasible because it meets the assumption of normality normal.

a. Statistical analysis

\begin{tabular}{|c|c|c|}
\hline \multicolumn{3}{|c|}{$\begin{array}{l}\text { Tabel } 4.8 \text { Normality Test Results } \\
\text { One-Sample Kolmogorov-Smirnov Test }\end{array}$} \\
\hline & & $\begin{array}{c}\text { Unstandardized } \\
\text { Residual }\end{array}$ \\
\hline N & & 57 \\
\hline \multirow[t]{2}{*}{ Normal Parameters a.b } & Mean & .0000000 \\
\hline & Std. Deviation & .15199112 \\
\hline \multirow[t]{3}{*}{ Most Extreme Differnences } & Absolute & .089 \\
\hline & Positive & .056 \\
\hline & Negative & -089 \\
\hline Test Statistic & & .089 \\
\hline Asymp, Sig. (2-tailed) & & $200^{\sigma, d}$ \\
\hline \multicolumn{3}{|c|}{ a. Test distribution is Normal. } \\
\hline \multicolumn{3}{|l|}{ b. Calculated from data. } \\
\hline \multicolumn{3}{|c|}{ c. Lilliefors Significance Correction. } \\
\hline
\end{tabular}

Source: Processed data, 2020

Through the output of the One-Sample Kolmogorov-Smirnov Test, it can be seen that the data from the application of the questionnaire is normally distributed because of the Asymp results. Sig dependent and independent variables of 0.200>0.05 means that the dependent and independent variables are normally distributed.

\subsubsection{Multicollinearity Test}

Tabel 4.9 Multicollinearity Test Results Coefficients $^{\mathbf{a}}$

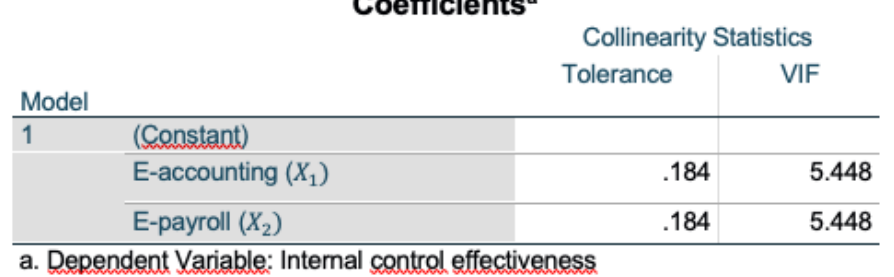

DOI: $10.52362 /$ ijiems.v1i1.706

IJIEMS This work is licensed under a Creative Commons Attribution 4.0 International License. 
International Journal of Informatics, Economics, Management and Science

http://journal.stmikjayakarta.ac.id/index.php/ijiems

E-ISSN: 2809-8471 (online), P-ISSN: 2809-9281 (Print)

DOI: $10.52362 /$ ijiems.v1i1.706

Volume 1 , Issue 1 , January 2022, page 78-101

Source: Processed data, 2020

Based on table 4.9, the results show that the tolerance value of each variable is 0.184 and 0.184 , greater than 0.10 and the VIF value for the independent variables is 5.448 and 5.448, respectively, smaller than 10 , so it can be concluded that there is no multicollinearity between independent variables.

\subsubsection{Heteroscedasticity Test}

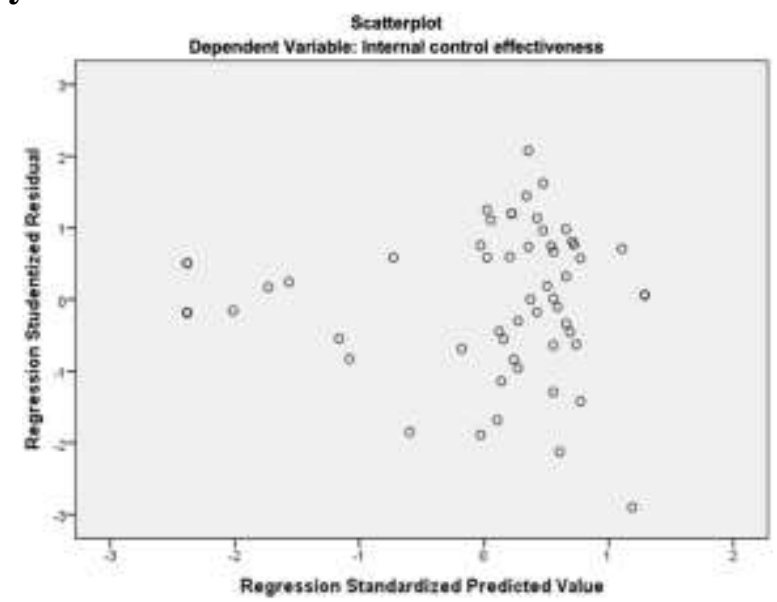

Source: Processed data, 2020

Figure 4.2 Scatterplot Test

Based on the results of the scatterplot graph above, it can be seen that there is no clear pattern and the points are spread above and below the number 0 . So, it can be concluded that the instrument used does not occur heteroscedasticity.

\subsubsection{Multiple Regression Analysis}

\begin{tabular}{|c|c|c|c|c|c|c|}
\hline \multicolumn{7}{|c|}{$\begin{array}{c}\text { Table 4.9 Multiple Regression Analysis } \\
\text { Coefficients }^{\mathrm{a}}\end{array}$} \\
\hline & & \multicolumn{2}{|c|}{$\begin{array}{l}\text { Unstandardized } \\
\text { Coefficients }\end{array}$} & \multirow{2}{*}{$\begin{array}{c}\text { Standardized } \\
\text { Coefficients } \\
\text { Beta } \\
\end{array}$} & \multirow[b]{2}{*}{$t$} & \multirow[b]{2}{*}{ Sig. } \\
\hline \multicolumn{2}{|c|}{ Model } & B & Std. Error & & & \\
\hline \multirow[t]{3}{*}{1} & (Constant) & .063 & .128 & & .487 & .628 \\
\hline & E-accounting $\left(X_{1}\right)$ & .713 & .086 & .716 & 8.251 & .000 \\
\hline & E-payroll $\left(X_{2}\right)$ & .269 & .088 & .264 & 3.047 & .004 \\
\hline
\end{tabular}

a. Dependent Variable: Internal control effectiveness

Source: Processed data, 2020

From the regression model above, it can be interpreted as follows:

a. E-accounting influences the effectiveness of internal control with a significance of 0.000 with a level of $=5 \%$. E-accounting has an effect of $71.3 \%$ on the effectiveness of internal control, marked by a B value in the Unstandardized Coefficients column of 0.713 . 
International Journal of Informatics, Economics, Management and Science

http://journal.stmikjayakarta.ac.id/index.php/ijiems

E-ISSN: 2809-8471 (online), P-ISSN: 2809-9281 (Print)

DOI: $10.52362 /$ ijiems.v1i1.706

Volume 1, Issue 1, January 2022, page 78-101

b. E-payroll influences the effectiveness of internal control with a significance of 0.004 with a level of $=5 \%$. E-payroll has an effect of $26.9 \%$ on the effectiveness of internal control marked by a B value in the Unstandardized Coefficients column of 0.269.

Based on the statement above, it can be seen that the effectiveness of internal control is more influenced by e-accounting by $71.3 \%$ compared to e-payroll by $26.9 \%$. This indicates that eaccounting is more effective in the effectiveness of internal control because the process is wider and is carried out by different departments compared to e-payroll only.

1. Correlation Coefficient and Determination Coefficient (R2)

Tabel 4.10 Correlation Test Result

Model Summary

\begin{tabular}{|c|c|c|c|c|c|}
\hline \multicolumn{6}{|c|}{ Model Summary } \\
\hline Model & $\mathrm{R}$ & R Square & $\begin{array}{l}\text { Adjusted R } \\
\text { Square }\end{array}$ & $\begin{array}{l}\text { Std. Error of } \\
\text { the Estimate }\end{array}$ & Durbin-Watson \\
\hline 1 & $.962^{\mathrm{a}}$ & .925 & .923 & .15478 & 2.046 \\
\hline
\end{tabular}

Source: Processed data, 2020

Based on table 4.10, it is found that the correlation coefficient of e-accounting and e-payroll variables with the effectiveness of internal control is 0.962 , meaning that there is a real and very strong relationship between the independent variable and the dependent variable.

Based on the value of the correlation coefficient above, the coefficient of determination of the e-accounting and e-payroll variables with the effectiveness of internal control can be calculated as follows:

$$
\mathrm{KD}=0,9622 \times 100 \%=92,5 \%
$$

The value of the coefficient of determination above states that the effect of e-accounting and e-payroll with the effectiveness of internal control is $92.5 \%$, meaning that the independent variable explains the dependent variable at $92.5 \%$. The remaining $7.5 \%$ is influenced by other variables outside the regression model in this study.

2. Partial Hypothesis Test (t-test)

The measurement used is by using a comparison of $t$ count and t table. For this reason, the following hypothesis is formed:

$\mathrm{H}_{\mathrm{o}}$ : the independent variable partially has no significant effect on the dependent variable.

$\mathrm{H}_{\mathrm{a}}$ : the independent variable partially has a significant effect on the dependent variable.

With the confidence level used is $95 \%$, then the value of $=0.05$.

If $t$ count $<t$ table then $\mathrm{H}_{\mathrm{o}}$ is accepted, and $\mathrm{H}_{\mathrm{a}}$ is rejected or if the value of Sig. $>0.05$. If $t$ count $>t$ table then $\mathrm{H}_{\mathrm{o}}$ is rejected, and $\mathrm{H}_{\mathrm{a}}$ is accepted or if the value of Sig. $<0.05$. The following is a table of $t$ test results:

\section{Tabel 4.11 Partial Parameter Test Results (t-test)}


International Journal of Informatics, Economics, Management and Science

http://journal.stmikjayakarta.ac.id/index.php/ijiems

E-ISSN: 2809-8471 (online), P-ISSN: 2809-9281 (Print)

DOI: $10.52362 /$ ijiems.v1i1.706

Volume 1, Issue 1, January 2022, page 78-101

\begin{tabular}{|c|c|c|c|c|c|c|}
\hline \multicolumn{7}{|c|}{ Coefficients $^{a}$} \\
\hline & & \multicolumn{2}{|c|}{$\begin{array}{l}\text { Unstandardized } \\
\text { Coefficients }\end{array}$} & \multirow{2}{*}{$\begin{array}{c}\text { Standardized } \\
\text { Coefficients } \\
\text { Beta }\end{array}$} & \multirow[b]{2}{*}{$\mathrm{t}$} & \multirow[b]{2}{*}{ Sig. } \\
\hline \multicolumn{2}{|c|}{ Model } & B & Std. Error & & & \\
\hline \multirow[t]{3}{*}{1} & (Constant) & .063 & .128 & & .487 & .628 \\
\hline & E-accounting $\left(X_{1}\right)$ & .713 & .086 & .716 & 8.251 & .000 \\
\hline & E-payroll $\left(X_{2}\right)$ & .269 & .088 & .264 & 3.047 & .004 \\
\hline
\end{tabular}

a. Dependent Variable: Internal control effectiveness

Source: Processed data, 2020

Based on the test results can be obtained results:

a. Hypothesis Testing 1

The first hypothesis proposed in this study states that e-accounting $\left(\mathrm{X}_{1}\right)$ influences the effectiveness of internal control (Y).

Based on the results of the partial parameter test ( $\mathrm{t}$ test) presented in table 4.15, the internal control effectiveness variable has $t$ count $=8.251$ with a significance level of 0.000 , this shows that $t$ count $>t$ table $(8.251>2.005)$ and the significance value (Sig.) $0.000<0.05$. So it can be concluded that $\mathrm{Ho}$ is rejected and $\mathrm{Ha}$ is accepted, which means "e-accounting partially has a significant positive effect on the effectiveness of internal control"

b. Hypothesis Testing 2

The second hypothesis proposed in this study states that e-payroll $\left(\mathrm{X}_{2}\right)$ influences the effectiveness of internal control.

Based on the results of the partial parameter test ( $\mathrm{t}$ test) presented in table 4.11, the e-payroll variable has a $\mathrm{t}$ count $=3.047$ with a significance level of 0.004 , this shows that $\mathrm{t}$ count $>\mathrm{t}$ table $(3.047>2.005)$ and a significance value (Sig.) $0.004<0.05$. So, it can be concluded that Ho is rejected and Ha is accepted, which means "e-payroll partially has a significant positive effect on the effectiveness of internal control"

3. Model Test / F Uji Test (Anova)

\begin{tabular}{|c|c|c|c|c|c|c|}
\hline \multirow[b]{2}{*}{ Model } & \multicolumn{6}{|c|}{ Tabel 4.12 $\underset{\text { ANOVA }^{\mathrm{a}}}{\mathrm{Uji}} \mathbf{F}(\mathrm{ANOVA})$} \\
\hline & & Sum of Squares & df & Mean Square & $\mathrm{F}$ & Sig. \\
\hline \multirow[t]{3}{*}{1} & Regression & 16.026 & 2 & 8.013 & 334.482 & $.000^{\circ}$ \\
\hline & Residual & 1.294 & 54 & .024 & & \\
\hline & Total & 17.320 & 56 & & & \\
\hline
\end{tabular}

Source: Processed data, 2020

According to [7] this $\mathrm{F}$ test has the aim of knowing whether the independent variables simultaneously or simultaneously affect the dependent variable. $\mathrm{F}$ table at a significance level of 0.05 with df 1 , the number of variables-1 $(3-1=2)$, and df $2(n k-1)$ or $57-2-1=54$, the

DOI: $10.52362 /$ ijiems.v1i1.706

IJIEMS This work is licensed under a Creative Commons Attribution 4.0 International License. 
International Journal of Informatics, Economics, Management and Science

http://journal.stmikjayakarta.ac.id/index.php/ijiems

E-ISSN: 2809-8471 (online), P-ISSN: 2809-9281 (Print)

DOI: $10.52362 /$ ijiems.v1i1.706

Volume 1, Issue 1, January 2022, page 78-101

results of the F table are 3.17. The results can be seen in table 4.12 that the $\mathrm{F}$ statistic value is 334.482 with a significance value of $0.000<0.05$ and $\mathrm{F}$ count $=334.482>\mathrm{F}$ table $=3.17$ which means e-accounting $\left(\mathrm{X}_{1}\right)$ and control system $\left(\mathrm{X}_{2}\right)$ together the same / simultaneous has a significant positive effect on the effectiveness of internal control $(\mathrm{Y})$. Based on the results above, $\mathrm{H}_{\mathrm{a}}$ is accepted, and $\mathrm{H}_{\mathrm{o}}$ is rejected

\subsubsection{Research Findings}

a. Effect of E-accounting ( $\left.\mathrm{X}_{1}\right)$ on the effectiveness of internal control (Y)

The use of the system makes it easier for companies to carry out company activities, one of which is e-accounting. If the e-accounting in a company is not adequate, then the company cannot process all transactions correctly so that the resulting information cannot be trusted. If the company is not able to produce information correctly, there will be errors in decision making. In e-accounting, there are elements of the effectiveness of internal controls that function to oversee all economic activities that occur in the company. The better the e-accounting implemented by the company, the more effective the effectiveness of internal control within the company. The results of this study indicate that the eaccounting variable $\left(\mathrm{X}_{1}\right)$ has a significant effect on the effectiveness of internal control (Y). The results of this study are consistently supported by the research of Sri Lestari Pebrianti, et al (2020) which shows the results that e-accounting has a significant effect on the effectiveness of internal control.

b. Effect of E-payroll $\left(\mathrm{X}_{2}\right)$ on the effectiveness of internal control (Y)

Companies need e-payroll that is effective and reliable so as to support the effectiveness of effective internal controls and prevent data fraud or errors. The better the e-payroll implemented by a company, the more effective the effectiveness of internal control in the company. As the results of this study that e-payroll has a positive and significant effect on the effectiveness of internal control. This is supported by research conducted by Rofily Putriyandari (2014) which shows the results that e-payroll has a positive and significant effect on the effectiveness of internal control. Likewise, research conducted by Rio Kencono (2016) states the same thing that there is an effect of e-payroll on the effectiveness of internal control.

c. Effect of e-accounting $\left(\mathrm{X}_{1}\right)$ and e-payroll $\left(\mathrm{X}_{2}\right)$ on the effectiveness of internal control (Y) In the implementation of e-accounting and e-payroll, there are systems and procedures that are carried out to form an effective internal control. In addition, there are documents, accounting records and reports that are used as the basis for running e-accounting and epayroll in the effectiveness of internal control. Based on the research results, e-accounting and e-payroll simultaneously affect the effectiveness of internal control. Regular e-

DOI: $10.52362 /$ ijiems.v1i1.706

IJIEMS This work is licensed under a Creative Commons Attribution 4.0 International License. 
International Journal of Informatics, Economics, Management and Science

http://journal.stmikjayakarta.ac.id/index.php/ijiems

E-ISSN: 2809-8471 (online), P-ISSN: 2809-9281 (Print)

DOI: $10.52362 /$ ijiems.v1i1.706

Volume 1 , Issue 1 , January 2022, page 78-101

accounting and e-payroll minimize the occurrence of errors and can even prevent fraud or fraud. Appropriate and well-executed e-accounting and e-payroll can affect the effectiveness of internal control so that the better the e-accounting and e-payroll of a company, the more effective the effectiveness of internal control on accounting and payroll.

\section{Conclusions And Suggestions}

Based on the results of the research that has been done, the conclusions from this study are:

1. E-accounting has a positive and significant effect on the effectiveness of internal control with a sig value. $0.000>0.05$ and the e-accounting variable describes the effectiveness of internal control of $71.3 \%$, marked by a B value of 0.713 .

2. E-payroll has a positive and significant effect on the effectiveness of internal control with a sig value. $0.004>0.05$ and the e-payroll variable describes the effectiveness of internal control of $26.9 \%$, marked by a B value of 0.269 .

3. E-accounting and e-payroll simultaneously have a significant positive effect on the effectiveness of internal control, indicated by the F statistic value of 334.482 with a significance value of $0.000<0.05$ and $\mathrm{F}$ arithmetic $=334.482>\mathrm{F}$ table $=3.17$ which means e -accounting (X1) and e-payroll $\left(\mathrm{X}_{2}\right)$ simultaneously have a significant positive effect on the effectiveness of internal control (Y).

The suggestions that can be submitted by researchers are as follows:

1. The e-accounting variable, the statement X1.7 "e-accounting can be operated comfortably during working hours without problems" is the lowest value, the company should pay more attention to the obstacles that arise when using e-accounting such as connectivity which is slightly slowed, and it is hoped that to perform regular system maintenance.

2. The e-payroll variable, the statement X2.6 "the list of salaries and wages is made individually with various kinds of information that forms it and shows the gross number of salaries and wages" is the lowest value, the company should provide more detailed and transparent salary slips regarding employee salary information.

3. The internal control effectiveness variable, the statement Y3 "There is a clear organizational structure and job description" is the lowest value, the company should ensure that the separation of responsibilities according to the job description becomes clearer and is applied with more discipline.

\section{References}

[1] Agoes, S. 2014. Auditing Petunjuk Praktis Pemeriksaan Akuntan oleh Akuntan Publik Jilid 1 Edisi Keempat. Jakarta: Salemba Empat. 
International Journal of Informatics, Economics, Management and Science

http://journal.stmikjayakarta.ac.id/index.php/ijiems

E-ISSN: 2809-8471 (online), P-ISSN: 2809-9281 (Print)

DOI: $10.52362 /$ ijiems.v1i1.706

Volume 1 , Issue 1 , January 2022, page 78-101

[2] Arikunto, Suharsimi. 2012. Prosedur Penelitian Suatu Pendekatan Praktek. Jakarta: Rineka Cipta

[3] Baridwan, Zaki. 2012. Sistem Akuntansi Keuangan. Edisi Kelima. Yogyakarta: BPFE.

[4] Baroroh, Ali. 2014. Analisis Multivariat dan Time Series dengan SPSS 21. Jakarta: PT. Elex Media Komputindo.

[5] Bodnar, George H and William S Hopwood. 2000. E-akuntansi. Jakarta: Salemba Empat

[6] COSO, 2017. Internal Control-Integrated Framework: Executive Summary, Durham, North Carolina, September 2017.

[7] Ghozali, Imam. 2013. Aplikasi Analisis Multivariate dengan Program IBM SPSS 21 Update PLS Regresi. Semarang: Badan Penerbit Universitas Diponegoro.

[8] Hartadi, Bambang. 1999. Sistem Pengendalian Intern dalam Hubungan Dengan Manajemen dan Audit. Yogyakarta: BPFE-Yogyakarta

[9] Hidayat, Mohammad Taufiq, et al. 2013. Analisis Penerapan Sistem Akuntansi Penggajian dan Pengupahan Dalam Mendukung Pengendalian Intern (Studi Kasus pada PT. Cahaya Marta Perkasa, Pamekasan). Jurnal

[10] Jogiyanto, 2007. Sistem Informasi Keperilakuan, Edisi Revisi, Yogyakarta: CV Andi

[11] Mulyadi. 2001. Sistem Akuntansi Edisi Ketiga Cetakan Ketiga. Jakarta: Salemba Empat

[12] Mulyadi, 2016. Sistem Akuntansi. Jakarta: Salemba Empat

[13] Pebrianti, Sri Lestari, et al. 2020. Pengaruh E-akuntansi Terhadap Efektivitas Pengendalian Internal pada PT Bosowa Berlian Motor Makassar. Jurnal.

[14] Rofily Putriyandari. 2014. Pengaruh E-akuntansi Penggajian Terhadap Efektivitas Struktur Pengendalian Intern pada Dinas Perkebunan Provinsi Jawa Barat. Jurnal.

[15] Rio Kencono. 2016. Pengaruh E-payroll Terhadap Efektivitas Pengendalian Internal Gaji (Studi Kasus Pada SPPBE PT Puspita Cipta di Kuningan). Jurnal

[16] Romney, Marshall B and Steinbart, Paul John. 2005. E-akuntansi Jilid 2 Edisi Sembilan. Jakarta: Salemba Empat

[17] Romney, Marshall B and Steinbart, Paul John. 2006. E-akuntansi. Jakarta: Salemba Empat

[18] Sarjono, Haryadi., dan Julianita, Winda. 2011. SPSS vs LISREL: Sebuah Pengantar, Aplikasi untuk Riset. Jakarta: Penerbit Salemba Empat.

[19] Sugiyono. 2018. Metode Penelitian Bisnis. Bandung: Alfabeta

[20] Susanto, A. 2013. E-akuntansi, Struktur Pengendalian Resiko Pengembangan, Edisi Perdana, Cetakan Pertama, Bandung: Lingga Jaya

[21] Tunggal, AW. 2013. Pokok-pokok Auditing dan Jasa Asuransi. Jakarta:Haryindo.

[22] William B. Werther, Jr., Keith Davis, 1993, Human Resource and Personnel Management, 4th edition, Singapore: Mc Graw - Hill International Edition.

DOI: $10.52362 /$ ijiems.v1i1.706

IJIEMS This work is licensed under a Creative Commons Attribution 4.0 International License. 